\title{
LETTERS
}

\section{Bill S-206 is ill-suited to achieve its stated objectives}

In their letter, Drs. Freeman and Piggott are correct about the harmful effects of violence and abuse on children, and that action to prevent the abuse of children is badly needed. ${ }^{1}$ Although their goal is laudable, I believe that Bill S-206 is illsuited to achieve its stated objectives. Bill S-206 would remove section 43 from the Criminal Code of Canada, which protects parents and those acting in their place from criminal prosecution for using "reasonable force"2 on children under age 12.

In 2004, the Supreme Court of Canada upheld this law and described the specific circumstances where this exemption would apply, substantially limiting the scope of this protection. Without Section 43, any physical contact with a child against their will could be considered an act of criminal assault, without differentiating between the use of corrective or restraining force and abuse or violence. In the words of the Supreme Court of Canada, removing section 43 would lead to "the reality of a child's mother or father being charged and pulled into the criminal-justice system" for "force falling far short of what we think of as corporal punishment." 3

As a family physician, I have asked parents to hold their squirming, sick child's head firmly so I could check for an ear infection. It would be an assault to restrain an adult in this way, and in the absence of Section 43, the child's parent and I would both have been committing a criminal offence. By criminalizing behaviour that every parent necessarily engages in, we open the door to selective enforcement, which, if history is any guide, will only further marginalize and criminalize members of groups already afflicted by discrimination.
We owe it to our patients to advocate for careful law-making and to promote solutions that will help achieve our goal of preventing child abuse without turning loving parents into criminals.

\section{Anthony D. Giordano MD}

Family physician, North Bay, Ont.

Cite as: CMAJ 2018 March 19;190:E337. doi: $10.1503 / \mathrm{cmaj} .68722$

\section{References}

1. Freeman LK, Piggott T. Supporting Bill S-206 protects Canadian children from violence [letter]. CMAJ 2017; 189:E1119.

2. Criminal Code (R.S.C., 1985, c. C-46).

3. Canadian Foundation for Children, Youth and the Law v. Canada (Attorney General), [2004] 1 SCR 76, 2004 SCC 4 (CanLII). Available: https://scc.csc.lexum.com/ scc-csc/scc-csc/en/item/2115/index.do (accessed 2018 Feb. 28).

Competing interests: None declared. 